\title{
Facing forward after Ebola: questions for the next director general of the World Health Organization
}

In light of heavy criticism of the WHO's handling of the Ebola outbreak, the election process for the next director general will be under intense scrutiny. Devi Sridhar and colleagues outline the key questions on epidemic preparedness for prospective candidates

Devi Sridhar professor of global public health ${ }^{1}$, Ilona Kickbusch director, global health programme ${ }^{2}$ , Suerie Moon research director, Harvard Global Health Institute ${ }^{3}$, Victor Dzau president ${ }^{4}$, David Heymann director ${ }^{5}$, Ashish K Jha professor ${ }^{3}$, Jorge Saavendra chief, global affairs ${ }^{6}$, Barbara Stocking president ${ }^{7}$, Liana Woskie assistant director, Harvard Initiative on Global Health Quality ${ }^{3}$, Peter Piot director ${ }^{8}$

${ }^{1}$ Edinburgh University Medical School, Edinburgh EH8 9AG, UK; ${ }^{2}$ Graduate Institute of International Studies, Geneva, Switzerland; ${ }^{3} \mathrm{Harvard}$ School of Public Health, Boston, USA; ${ }^{4}$ National Academy of Medicine, Washington DC, US; ${ }^{5}$ Centre for Global Health Security, Chatham House, London, UK; ${ }^{6}$ AIDS Healthcare Foundation, Mexico City, Mexico; ${ }^{7}$ Murray Edwards College Cambridge University, Cambridge, UK; ${ }^{8}$ London School of Hygiene and Tropical Medicine, London, UK

When the member states of the World Health Organization (WHO) elect a new director general in May 2017, they will decide the future of the organisation. The agency needs a strong global health leader determined to regain the trust of the international community and to position WHO in a rapidly changing environment. ${ }^{1}$ The history of director general elections indicates that member states consider many factors when choosing a candidate: political alliances, diplomatic deals, and regional considerations all come into play. This makes it hard to decide on the best candidate for the job.

We were members of three independent panels that have met over the past year to review the responses to the Ebola crisis, especially the work of the WHO. ${ }^{2-4}$ Our panels agreed that strong leadership was essential in the face of health crisis, and we are concerned about where director general candidates stand on the challenges faced by global and national organisations responding to a health emergency (any event that creates a health risk to the public) or disease outbreak. In contrast to the election of the UN secretary general, there is no provision for public debate with the director general candidates so we have chosen this way of catalysing discussion. Our questions aim at clarifying the candidates' position on what policies and procedures need to be instituted before the next health crisis occurs and how they see the leadership challenges ahead of them. These questions can be used by member states, civil society organizations, and the broader public to further probe candidates' positions.

\section{How important is WHO's role in health emergency and outbreak response and what is required of the director general to make this role a success?}

Since the 19th century, cross-border disease control has been the primary rationale for intergovernmental health cooperation. ${ }^{2}$ Disease outbreaks are foundational to the mandate of the WHO, yet its capacity to respond to outbreaks was deeply and disproportionately cut in the latest budget cycles. Faced with a broad and universal mandate - to achieve health for all people-and varied expectations from member states, the politically elected director general has a crucial role in setting the priorities of the organisation and ensuring agreement of the governing bodies. Our panels agree that a key attribute should be proved high level political leadership with the character and capacity to challenge even the most powerful governments when necessary to protect public health.

We would welcome candidates' reflections on the priorities for the agency during their tenure and on the difficult decisions that will be required. Specifically, for health emergency and outbreak response, how do candidates intend to guide commitment through governing bodies and implement a strategy at all levels of the organisations, from headquarters through to regional and country offices? 
BOX: Timeline for nominating and appointing WHO's director general ${ }^{8}$

22 September 2016: Deadline for member states to put forward names of candidates

January 2017: WHO executive board will draw up a shortlist of up to five candidates, and following interviews will nominate up to three candidates for the final shortlist

May 2017: Member states vote using a secret ballot at the World Health Assembly

July 2017: New director general will take office

\section{How is WHO's work in health emergency and outbreak response related to other priority areas in the sustainable development goal on health, especially universal health coverage?}

Sustainable development goal 3 sets out targets to ensure healthy lives and promote wellbeing for all at all ages, including achieving universal health coverage. We and others have argued that outbreak preparedness and response must be integrated into a larger vision of human security. ${ }^{5}$ A narrow health security definition - especially one that focuses on national securitymight result in attention being paid only to diseases that could be imported to wealthier countries and populations. Conversely, a too narrow understanding of universal health coverage, such as limitation to financial protection, may not serve priority concerns related to equity, public health, health promotion, and disease prevention. The development of resilient health systems is a key component of ensuring better population health but cannot alone ensure an adequate response in the case of a global emergency. The new director general will need to consider this complex interface as part of the work on reaching sustainable development goal 3.

\section{How should the health emergency and outbreak response be financed?}

WHO's budget is split between assessed contributions (what member states must pay, around $20 \%$ of the total budget) and voluntary contributions from member states and other donors (around 80\%). ${ }^{6}$ This financing model makes the agency vulnerable. The new director general will have to find an agreement with member states on how to ensure the financing of the WHO's work in general and how to support the agency's core work in health emergency and outbreak response, including the contingency fund-a financial mechanism established in May 2015 to rapidly support WHO emergency operations for up to three months before other resources are made available. Should this be financed through increased assessed contributions, a special fund, a percentage of voluntary contributions, or other innovative mechanisms?

More widely, financing is essential to build core capacities across the world, create financing facilities for research and development, and ensure rapid disbursement of cash during emergencies. Two of our panels have suggested establishing a global financing facility for research and development of health technology relevant to major disease outbreaks. ${ }^{24}$ It could support manufacturing, research, and development for drugs, vaccines, diagnostics, and other non-pharmaceutical supplies (such as personal protective equipment) where the commercial market does not offer appropriate incentives. In addition, the World Bank is proposing a pandemic emergency financing facility that would rapidly disburse funds to affected countries. The Global Health Security Agenda, a US launched and G7 supported initiative to improve adherence to International Health Regulations, has committed $\$ 1$ bn to build core capacities in at least 30 developing countries. Which of these mechanisms should be taken forward?

\section{What can and should WHO do to strengthen member states' capacity and accountability for adherence to International Health Regulations?}

Preventing small scale outbreaks from becoming large scale emergencies needs a minimum level of core capacities in all countries to detect, report, and respond rapidly. Governments committed to developing core capacities by 2012 under the International Health Regulations, but in 2015 two thirds of member states had not met their requirements. ${ }^{2}$ In addition, during the Ebola outbreak, 40 countries and many private firms implemented restrictions on travel or trade, despite WHO's recommendations against such measures and the UN Security Council's warnings about the resulting isolation of affected countries.

Candidates might wish to reflect on the strategies they would implement in order to increase compliance with the regulations and to consider what other organisations - such as the International Monetary Fund, the World Trade Organisation, or the International Civil Aviation Organisation-WHO should work with to move this agenda forward.

\section{Do we need to change the procedure for declaring a public health emergency of international concern?}

Responsibility for declaring a public health emergency currently rests with the director general, who convenes an emergency committee of independent experts for a recommendation.

Concerns were expressed that the current director general was too late to declare Ebola a public health emergency. ${ }^{2}$ There are risks in vesting such consequential power in a single individual, who might be put under political pressure by certain governments, especially if there is no institutional mechanism of accountability for leadership failures.

Changes are already under way in relation to declaring public health emergencies. ${ }^{9}$ We would welcome candidates' views on the decision making process, including how the director general can best balance political pressure and global health concerns, and how transparency and accountability can be strengthened.

\section{How operational should the WHO be in relation to health emergency and outbreak response and how should its response-from headquarters to regional to country level—be organised?}

All three of our panels have proposed the creation of a unified WHO Centre for Emergency Preparedness and Response..$^{2-4}$ The centre could assess risks on the basis of the information that 
countries and others provide to WHO and mobilise necessary laboratory, epidemiological, clinical, communications, and logistical responses. It would also build a certified virtual global health workforce.

What are the candidates' reflections on the steps already undertaken to implement such an approach, and what remains to be done at the level of the headquarters, regional offices, and country offices of the organisation?

\section{How actively should WHO engage in coordinating the research required to better prepare for outbreaks?}

Producing and rapidly sharing knowledge during outbreaks is essential. Reliable systems for rapid transmission of epidemiological, genomic, and clinical data were not established during the Ebola epidemic. One of our panels therefore proposed that WHO should convene governments, the scientific research community, industry, and non-governmental organisations to develop a framework of norms and rules for research relevant to disease outbreaks. ${ }^{2}$

Other questions on research for candidates to consider include whether WHO should engage in research itself, how the private sector should engage, and what WHO can do to ensure both innovation and equitable access to vaccines, drugs, and other health technologies and diagnostics for outbreaks.

\section{How can WHO work effectively across organisations and sectors as the UN cluster lead for health emergencies?}

An effective global system for preventing and responding to outbreaks needs well coordinated and appropriately resourced organisations to fulfil clearly defined roles and responsibilities and to hold each other accountable for doing so. The international humanitarian system, including the Office for the Coordination of Humanitarian Affairs, Unicef, the World Food Programme, the UN High Commissioner for Refugees, and non-governmental organisations, are responsible for mounting an effective operational response if an outbreak escalates into a humanitarian crisis. It also requires coordination across national governments. What would be the key components of a UN-wide response- and what should the WHO's relationship with the UN's emergency response coordinator be? Given that the effective management of health crises often exceeds the remit of health ministries and WHO, candidates should also consider how best to engage political leaders.

\section{How should the relationship between the director general and the UN secretary general be formalised, especially during a public health emergency?}

There is currently no formal relationship between the director general of the WHO and the UN secretary general when a public health emergency is declared. There is agreement among our panels that this relationship should be strengthened. There have also been proposals for a high level global health group that sits within the UN, either as part of the Security Council or the General Assembly. ${ }^{2}$

\section{How should WHO engage with non-state organisations on health emergency and outbreak response while balancing its responsibilities to member states as a UN intergovernmental organisation with promoting the right to health of individuals and communities?}

WHO's near universal state membership, governance structure (including the one country, one vote system), and deep relationships with health ministries have given it a unique position in the international architecture. It is presently engaged in difficult negotiation over its relationship with non-state organisations, including the private sector and civil society organisations. During the initial and later stages of the Ebola epidemic civil society organisations had a key role not only in delivering services to places where governments usually cannot go, but also in mobilising communities to protect themselves. WHO also had to engage with the private sector in relation to rapid research and development. Candidates should reflect on the strategies and reform they consider essential for effective engagement in outbreak response, including balancing its responsibilities to member states with promoting the right to health of communities and individuals directly.

\section{What independent assessment and accountability mechanisms are required for WHO's role in emergency response?}

Candidates will need to consider how accountability can be strengthened in relation to health emergency and outbreak response. Should there be a regular, independent global health security report or another accountability mechanism that assesses overall system performance, such as the creation of a freedom of information policy and an inspector general at the WHO?

Much of the criticism of UN institutions and their response to crisis and emergencies is the lack of scrutiny over what interventions have taken place, whether these were appropriate and effective, and if financing flows have accomplished what they were committed to do. One proposal outlines the creation of an accountability commission, an independent body comprised of civil society, academia, and independent experts doing real time and retrospective system-wide assessment of global responses to major disease outbreaks. ${ }^{2}$ The UN secretary general's high level panel on emergency response has proposed establishing a high level council on global public health crises. ${ }^{7}$

\section{Conclusion}

Our primary goal is to convince political leaders worldwide to reflect hard on the type of director general they want to lead the WHO. While our questions have focused on global health security they touch on many other areas of global health and the work of the WHO. They show the different facets of leadership that are required to ensure that WHO has a key role in the coming years and decades and that an Ebola-like crisis never happens again. Business as usual cannot continue; transformative leadership is called for.

Contributors and sources: This article originated from discussions among the coauthors about the lessons from Ebola for the election of the next director general based on all three of our panel's work. BS (chair) and IK served on the WHO Interim Assessment Panel. PP (chair), DS 
(cochair), AJ (cochair), SM (study director), LW (research assistant), $\mathrm{DH}$, and JS served on the Harvard-LSHTM independent panel on the global response to Ebola. VD is president of the National Academy of Medicine, which coordinated the third panel. DS wrote the first draft of the paper based on questions drafted by IK, SM, and LW. All authors edited and commented on this draft. All authors approved the final version.

Competing interests: We have read and understood BMJ policy on declaration of interests and declare that we have no competing interests. Provenance and peer review: Commissioned; externally peer reviewed.

1 Checchi F, Waldman RJ, Roberts LF, et al. World Health Organization and emergency health: if not now, when?BMJ 2016;352:1469. doi:10.1136/bmj.i469 pmid:26821569.

2 Moon S, Sridhar D, Pate MA, et al. Will Ebola change the game? Ten essential reforms before the next pandemic. The report of the Harvard-LSHTM independent panel on the global response to Ebola. Lancet2015;386:2204-21. doi:10.1016/S0140-6736(15)009460 pmid:26615326.
3 World Health Organization. Report of the Ebola interim assessment panel. WHO, 2015. National Academy of Medicine Commission on a Global Health Risk Framework for the Future. Final report: the neglected dimension of global security: a framework to counter infectious disease crises. NAM, 2016.

5 Heymann DL, Chen L, Takemi K, et al. Global health security: the wider lessons from the west African Ebola virus disease epidemic. Lancet 2015;385:1884-901. doi:10.1016/ S0140-6736(15)60858-3 pmid:25987157.

6 Sridhar D, Frenk J, Gostin L, Moon S. Global rules for global health: why we need an independent, impartial WHO. BMJ 2014;348:g3841. doi:10.1136/bmj.g3841 pmid: 24942299.

7 UN. Protecting humanity from future health crises: report of the high-level panel on the global response to health crises. 2016. http://www.un.org/News/dh/infocus/HLP/2016-02 05_Final_Report_Global_Response_to_Health_Crises.pdf.

8 WHO. Process to elect next Director-General of WHO begins. Press release, 22 April 2016. http://www.who.int/mediacentre/news/releases/2016/election-process/en/)

9 WHO. Follow up to the World Health Assembly decision on the Ebola virus disease outbreak and the special session of the executive board on Ebola: roadmap for action, September 2015. http://www.who.int/about/who_reform/emergency-capacities/WHOoutbreasks-emergencies-Roadmap.pdf?ua $=1$.

Published by the BMJ Publishing Group Limited. For permission to use (where not already granted under a licence) please go to http://group.bmj.com/group/rights-licensing/ permissions 